\title{
E-Banking and Service Delivery in Eco Bank Nigeria a Comparative Analysis
}

\author{
OtokpaOgenyi \& Okpe, Isa. J.Ph.D. \\ Department of Economics \\ Benue State University \\ Makurdi
}

\begin{abstract}
This study investigates E-banking and service delivery at Ecobank Nigeria in Benue State. A purposive sampling technique was employed to identify specific Users and Non-users of E-banking facilities. The respondents in each group were randomly selected to avoid selection bias. Questionnaire and Oral interviews were used to collect data for this study. A Sample of 400 Users of E-banking and 395 Non-user of e-banking products of Ecobank Nigeria was selected. Descriptive tools such as tables, percentages, charts, ratios, and averages were used. Statistical analysis, specifically the Kolmogorov-Smirnov test, Shapiro-Wilk, and Satter Thwaite-Welch t-tests were used. The results showed that there is a significant difference between the time spent on the queue by Users and Non-users of E-banking at Ecobank Nigeria in Benue State in favor of the Users of E-banking (3.287 minutes for Users and 33.07 minutes for Non-users). The study also revealed that there is a significant difference in the financial cost for using E-banking ( $\$ 80.51)$ and banking hall services ( $\$ 274.81)$ also in favor of the Users of Ebanking. The major problem faced in the use of E-banking as indicated by the users is network failure while the Non-users spend longer time (33.07 minutes) on queue to obtain financial services. The study, therefore, recommended that banks should invest more on Information and Communication Technology (ICT); in higher version of radio-wave like fiber and subscribe to Internet Service Provider (ISP) with higher bandwidth to enable them to render the expected service to the end-users instead of relying heavily on other internet network providers.
\end{abstract}

Keywords: Ecobank, E-banking, service delivery, Users and Non-users

\section{Introduction}

The emergence and growth of E-banking have been made possible following the revolution and rapid development in the Information and Communication Technology (ICT). This has had a profound impact on the banking industry and the wider financial sector in Nigeria over time. Berger (2003) opined that its utilization has increased in the service industry particularly the banking sector as it created an enabling environment for banks to differentiate their products and services to meet the challenges of market competition among other things. Baraghani (2008) reaffirmed that banks have found that they have to constantly innovate and update to retain their demanding and descending customers and to provide convenient, reliable and expedient services. The E-banking has now become a tool that facilitates the bank's operations, business strategies and effective customer services delivery. Owing to this foregoing, Ranee (2008) asserted that the recent "ICT revolution" has exerted a farreaching impact on economies in general, and the financial services industry in particular. Driven by the challenge to expand and capture a larger share of the banking market, almost all banks in Nigeria have implemented a more revolutionary approach to deliver their banking services via the internet medium (Internet Banking).

In Benue state, there are sixteen (16) commercial bank branches. These banks provide E-banking facilities and banking hall services. The E-banking products offered by these banks in Benue State are the same in services provided but differ only in nomenclature such as First bank ATM, Zenith bank ATM, Access bank Mobile Money etc. However, the number of ATM terminals among the banks differs in quantity. There are one hundred and forty-five (145) functional ATM terminals in Benue State; of these numbers, Ecobank has seventeen (17) which is about $12 \%$ of the total number of functional ATM terminals in Benue state. These bank's ATM terminals are interconnected with aid of the internet through inter-switch company thereby making it possible for other bank's customers to carry out financial transactions on another bank's ATM without attracting extra financial cost to the users. 
Another E-banking platform is Ecobank Mobile Money. This is a phone (mobile phone) based business developed to expand activities in the area of mobile financial services. It is operational anywhere provided there is the availability of GSM network. It is interesting to know that Ecobank Mobile Money services can also be access by non-customers of Ecobank through the bank's mobile money agents. All these innovations are geared towards efficient service delivery in the services industry especially the banking sub-sector, however, a good number of customers up till now prefer using the banking hall services instead of the alternative electronic channels made available in the bank. Thus, this study seeks to unravel how efficient is E-banking to service delivery at Ecobank Nigeria in Benue State.

\section{Conceptual Framework}

One of the determinants of E-banking and service delivery by Ecobank Nigeria is Time Spent on the Queue. It is assumed in this study that service is delivered if the time spent on the queue is 10 minutes or below. The best practice in Ecobank Nigeria specifies 5minutes turnaround time for cash deposits and withdrawals and 8 minutes for assessing bank drafts. However, considering the speed and fluctuation of internet services, 10minutes is assumed in this work. Financial Cost involves the cost associated with the use of banking hall services or Ebanking facilities (ATM) as regards transportation cost and the cost of services received. It is assumed that services are delivered if the cost incurred for accessing bank services is $\$ 100$ and below. The Number of functional ATM terminals available for use is also another important factor. These include both Ecobank and other bank's ATMs. ATM functionality is defined in terms of ability to perform any of the services such as balance inquiry, cash withdrawal, phone recharge, and fund transfers. In this study, service is delivered if $50 \%$ of the available ATM terminals are able to perform any of the above-mentioned services. Average Network up Time is also considered: This has to do with the availability of internet network connectivity on ATM terminals, GSM handset for the purpose of Mobile Money transactions and in the banking hall. Services can be said to be delivered if only there is $80 \%$ the availability of internet network of the time customers goes to use the ATM terminals though, the best practice of Ecobank Nigeria is $99.99 \%$.

\section{Empirical Review}

In order to find out the response level of the elderly in terms of technology adaptation in the banking sector Zeithaml and Gilly (1987) used questionnaires on 2500 elderly respondents and observed that the elders are more responsive to the use of scanners electronic fund transfer but are averse to the use of automatic teller machine while Marshall and Heskop (1988) used Cronbach's alpha to ascertain the demographic factors that influence the use of ATM. Demographic factors such as higher education levels and employment status were positively related to the usage of ATMs while age was negatively related to the adoption of ATMs.Leblanc (1990) used Chi-square to find out consumer motivation for using ATMs and discovered that the use of technology in banking sector improved service quality, with little security risk and it also fulfilled their need for simple and fast transactions. It was found out that non-users of ATMs preferred interacting with human tellers and perceived ATM usage to be complex and risky. Lewis (1991) found that customers mainly used ATMs for withdrawal of cash and obtaining account balances. But also found that customers are mainly concerned about their personal safety, lack of privacy and operational problems such as machine being regularly out of cash or out of order, and cards getting stuck in it. Rugimbana and Iversen (1994) found that ATM customers mostly used ATM for cash withdrawal and conducted less than $50 \%$ of their transactions through it. The study concluded that most users perceived ATMs to be convenient cash dispensers, while the non-users preferred contact with human tellers and hence had a need for personal service. Sathye (1999) examined the factors affecting the adoption of Internet banking by Australian consumers. Descriptive analyses were used in examining the ATM variables while ANOVA was used to determine the differences in perception of customers. The study found that security concerns and lack of awareness about Internet banking and its benefits stand out as being the obstacles to the adoption of internet banking in Australia.

Polatogulu and Ekin (2001) conducted an exploratory study of consumer acceptance of internet banking services in a Turkish bank. Frequencies and percentages, as well as multiple regression analyses, were used and hinted that internet banking reduces the operational cost to the bank and enhances customer satisfaction and retention.

Bello (2005) investigated the impact of E-banking on customer satisfaction in Nigeria with a major focus on First Bank Nigeria Plc, Zenith Bank Plc and Guaranty Trust Bank Plc in Lagos, Port Harcourt, and Kaduna. The study used primary data and the result was presented using descriptive statistics and analyzed the same using Chi- 
square. The study found out that many banks' customers in Nigeria are fully aware of the positive developments in information technology and telecommunications. Malhotra and Singh (2006) examined the impact of internet banking on bank performance in India with a major focus on the users and non- users of internet facility. A univariate statistical analysis was used and the findings revealed that internet banks have better accounting efficiency ratios and higher returns on equity and returns on assets than non-Internet banks. However, the multiple regression results reveal that the profitability and offering of Internet banking do not have any significant association.

Arnaboldi and Claeys (2008) compared the performance of 'click and mortar' model of banking with internet banking across countries in Europe such as Finland, Spain, Italy, and the UK over the period of 1995-2004. A fuzzy cluster analysis on the performance of banks shows that internet banks are hard to distinguish from banks that follow a click and mortar strategy. The study also found that the strategy of banking groups to incorporate internet banks reflects some competitive edge that these banks have in their business models and extensive technological innovation boosts internet banking.

Osabuohien (2008) used cross tabulation to assess the efficacy of ICT in the banking sector in Nigeria. Primary data were employed to generate information for the study and the result shows that bankers' age, educational qualification, computer literacy and type of ICT gadgets influence banks' degree of ICT usage, while ICT impacts significantly on the speed of banking operations, productivity, and profitability. Auta (2010) used Kaiser-MeyarOlkin (KMO) approach and Barlett's Test of Sphericity to assess the impact of E-banking on 25 commercial bank customers and staff. The result shows that E-banking has played a significant role in the Nigerian banking sector while Antony (2011) used the Chi-square test which revealed that E-transaction has an overwhelming impact on customer satisfaction. In terms of human resource performance and customer satisfaction, Olanipekun, Brimah, and Ajagbe (2013)used a Chi-square test on fifty respondents. The findings revealed that electronic banking has impacted positively on the bank's human resource performance while Abaenewe (2013) revealed a mixed result about the impact of e-banking on Returns on Equity (ROE) of Nigerian banks.

Okiro and Ndungu (2013) assessed the impact of mobile and internet-banking on the performance of financial institutions in Kenya using descriptive statistics. The study observed that the most prevalent internet banking service is balance inquiry and cash withdrawal while the least is online bill payment and purchasing commodities. In Zimbabwe Muzividzi, Mbizi and Mukwazhe(2013) used questionnaires and interview to elicit information from respondents and hinted that internet banking is convenient and cheaper to use than the analogue type of banking and saves time. They observed that security played an important factor in the adoption and non-adoption of internet banking platform while in Malaysia, Hong, Teh, Vinayan, Soh, Khan, and Ong (2013) revealed that complexity, security and customer experience were the influencing factors of Internet banking services in the area. Similarly, Ling, Fern, Boon, and Huat, (2015) used questionnaires on 200 participants in Malacca, Malaysia and found out that web design and content, security and privacy, convenience and speed greatly influence consumer satisfaction in the study area.

Ogunlowore and Oladele (2014) investigated the problem of internet banking on customer satisfaction in GTB in Lagos on 100 respondents. Using ratios and chi-squares the findings show the problems faced are the poor infrastructural facility, high illiteracy rate, poor regulation of e-banking structure as well as high cost and charges of text messages. Mohammed, Aminul and Lakkhan (2015)used regression, factor analysis, and reliability test to ascertain internet satisfaction with regard to ATM and found that cost of service of ATM, ATM network, security, location and withdrawal limit play prominent role in customer satisfaction in Dhaka city, Bangladesh while Sailaja\& Thamodaran (2016) looked at the security of ATM facilities and observed a tripartite significant relationship between E-banking, service delivery, and cost effectiveness but observed that there is a rise in ATM crime in Indian.

\section{Theoretical Framework}

The consumer acceptance of technology theory has been adopted as a theoretical framework for the research work. This theory is considered relevant in explaining bank's services delivery to users through E-banking because it takes into consideration the perceived usefulness of technology innovation which in this case is Ebanking as well as the relative advantage of the new technology (E-banking) in relation to other alternatives. These key aspects of the theory form the basis with which users can evaluate the services delivered by the bank. 
The aspect of the relative advantage as theorized by the consumer acceptance model states that individuals are more likely to adopt innovations that have perceived advantages than they are to buy products which have little or no additional benefits over the alternatives. As described by Rogers (2003), relative advantage means that the innovation is believed by the adopter to be superior in some way to what it is intended to supersede. This goes that the services rendered by banks through E-banking are more effective as compared to the previous analog banking which is the reason for users to adopt and accept the innovation in banking technology (E-banking)

\section{Methodology}

The survey design was employed in this study. The data were collected using questionnaires. The study employed a purposive sampling technique to elicit the desired information from Users and Non-users of the Ebanking facilities. The data were analyzed using descriptive and inferential statistics such astables, percentages, charts, ratios, and averages while the Kolmogorov-Smirnov test, Shapiro-Wilk test, and Satterthwaite-Welch test were used.

A pre-survey report reveals that there are five branches of Ecobank in Benue state. The breakdown of the population of the branches is stated in table 1. Makurdi has a total customer base on 86,923 with 67,254 users of E-banking and 19,669 on non-users. Otukpo has a customer base of 30,000 with 21,000 and 9,000 users and nonusers of E-banking products while Gboko branch has a customer base of 25,000 out of which 18,750 users and 6,250 non-user of banking products. A total customer base of 141, 923 were observed in the three branches made up of 107,004 users and 34,919 non-users of the products.

Table 1: Users and Non-Users of Ecobank E-Banking Products

\begin{tabular}{|l|l|l|l|}
\hline BRANCH & CUSTOMER BASE & $\begin{array}{l}\text { USERS OF E-BANKING } \\
\text { PRODUCTS }\end{array}$ & NON-USERS \\
\hline Makurdi Branches & 86,923 & 67,254 & 19,669 \\
\hline Otukpo & 30,000 & 21,000 & 9,000 \\
\hline Gboko & 25,000 & 18,750 & 6,250 \\
\hline TOTAL & $\mathbf{1 4 1 , 9 2 3}$ & $\mathbf{1 0 7 , 0 0 4}$ & $\mathbf{3 4 , 9 1 9}$ \\
\hline
\end{tabular}

Source: Ecobank, 2014.

The sample size for each branch was determined using Yameni (1967) sample size determination. Therefore, a sample of 400 users of E-banking was selected while 395 for non-users were selected. Therefore a total of 795 were selected for both users and non-users. However, a total of 378 representing $94.5 \%$ were retrieved from the Users and 322 representing $82 \%$ were retrieved from the Non-users of E-banking at Ecobank Nigeria in Benue State.

Table 2: Descriptive Statistics for Users and Non-users on Financial Cost.

\begin{tabular}{|l|l|l|}
\hline & Users & Non-users \\
\hline & Financial Cost ( $)$ & Financial Cost (\#) \\
\hline Statistics & Values & Values \\
\hline Mean & 80.51 & 267.39 \\
\hline Minimum & 0.00 & 250 \\
\hline Maximum & 100.00 & 350 \\
\hline Standard Deviation & 41.85 & 40.54 \\
\hline Skewness & -1.32 & 1.46 \\
\hline Kurtosis & -0.26 & 0.12 \\
\hline Jacque-Bera & 58.59 & 44.70 \\
\hline
\end{tabular}

Source: Author's computation using E-views.

Table 2 shows the descriptive statistics on financial cost for Users and Non-users of E-banking at Ecobank Nigeria in Benue State. For the Users, the table reveals that the mean financial cost of $\$ 80.51$ on transportation cost to ATM point and cost of transactions, with a minimum cost of $\$ 0.00$ and a maximum cost of $\$ 100.00$.

The standard deviation of $\$ 1.85$ was observed. This implies that variation in the financial cost from one User of E-banking to another is approximately $\$ 1.85$. The skewness and kurtosis indicate that the financial cost of using E-banking at Ecobank Nigeria in Benue State is skewed to the left. However, it is not too extreme; hence the financial cost is normally distributed. 
For the Non-users, the mean financial cost of using banking hall is $\$ 267.39$ with a minimum cost of 250 and the maximum value of $\$ 350$; while the variation in the cost from one Non-user to another (standard deviation) is \$40.54. The skewness shows that the cost is positively skewed, while the kurtosis shows that the cost is not over peaked. The difference in the mean financial cost for Users and Non-users is 186.88 in favor of Users of Ebanking.

The Jacque-Bera values of 58.59 and 44.70 with corresponding probabilities of 0.0000 and 0.0000 (less than 0.05 critical level) for the financial cost of using E-banking and Banking hall respectively, indicated that the data used for the study is normally distributed and thus estimates from it are expected to be unbiased and reliable.

Table 3: Descriptive Statistics for Users and Non-users on Time Spent

\begin{tabular}{|l|l|l|}
\hline & Users & Non-users \\
\hline & Time Spent (in minutes) & Time Spent (in minutes) \\
\hline Statistics & & \\
\hline Mean & 3.24 & $\mathbf{3 6 . 3 1}$ \\
\hline Minimum & 1.00 & $\mathbf{4 . 0 0}$ \\
\hline Maximum & 10.00 & 60.00 \\
\hline Standard Deviation & $\mathbf{2 . 0 0}$ & $\mathbf{1 5 . 0 0}$ \\
\hline Skewness & $\mathbf{2 . 0 0}$ & $\mathbf{0 . 2 7}$ \\
\hline Kurtosis & $\mathbf{4 . 1 1}$ & $\mathbf{- 0 . 6 0}$ \\
\hline Jacque Bera & 295.93 & $\mathbf{2 8 . 8 0}$ \\
\hline
\end{tabular}

Source: Author's Computation using E-views.

Table 3 shows the time spent on the queue for Users and Non-users of E-banking at Ecobank Nigeria in Benue State. For Users, the table reveals a mean time spent of 3 minutes and 24 seconds, with a minimum time spent of 1.00 minute and a maximum of 10 minutes. A Standard Deviation (SD) of 2 minutes was observed. The skewnessof 2 minutes and kurtosis of 4.11 minutes which is relatively higher than the conventional value of 3 this shows that the time used on the queue is relatively high. For Non-users, the mean time spent is 36 minutes and 31 seconds with a minimum value of 4 minutes and a maximum value of 60 minutes. The standard deviation which measures the variation of time spent by one Non-user and the other is 15 minutes. The difference in the mean time spent by Users ( 3 minutes and 24 seconds) and Non-users (36 minutes and 31 seconds) of E-banking is 33 minutes and 12 seconds. The Jacque-Bera values of 295.93 and 28.80 with corresponding probabilities of 0.0000 and 0.0000 (less than 0.05 critical level) for the time cost (in minutes) of using E-banking and for the time cost (in minutes) of using banking hall respectively indicated that, the data used for the study is normally distributed and thus estimates from it are expected to be unbiased and reliable.

Table 4: The Number of Functional ATM Terminals at Ecobank Nigeria in Benue State.

\begin{tabular}{|l|l|l|}
\hline Branches of Ecobank & Number of ATM & Number of Functional ATMs \\
\hline Old Otukpo Road, Makurdi & 6 & 5 \\
\hline OgiriOkoh Road, Makurdi & 4 & 4 \\
\hline Gboko Road, Makurdi & 3 & 3 \\
\hline Gboko Town & 2 & 2 \\
\hline Otukpo Town & 2 & 2 \\
\hline Total & $\mathbf{1 7}$ & $\mathbf{1 6}$ \\
\hline
\end{tabular}

Source: Ecobank Newsletter, 2014.

Table 4 shows that there are 17 ATMs of Ecobank Nigeria across Benue State of which 16 ATM terminals are functional; representing $94.12 \%$ of the total available ATM terminals in the state. The implication is that only $5.88 \%$ of the total ATM terminals are not functional. This implies that there are 16 outlets in addition to other bank's 128 ATM terminals as at 2014 to access cash by Users of E-banking as compared to just 5 outlets (Ecobank Nigeria branches) available for use by the Non-users of E-banking.

This makes cash easily accessible and at any time as compared to 5 branches of Ecobank Nigeria in Benue State that only operates within the official opening days and hours. Furthermore, the Users were asked whether they have access to other banks' ATM terminals. Their responses are presented in Table 5. 
Table 5: Users Access to other banks' ATM Terminals.

\begin{tabular}{|l|l|l|}
\hline Responses & Frequency & Percentage \\
\hline Have Access & 378 & 100.00 \\
\hline Do not have Access & 0 & 0 \\
\hline Total & $\mathbf{3 7 8}$ & $\mathbf{1 0 0 . 0 0}$ \\
\hline
\end{tabular}

Source: Field Survey, 2014.

Table 5 shows that all the users of ATM at Ecobank have indicated that they have access to other banks' ATM terminals. The implication is that accessibility to and usage of E-banking is not a challenge since they can easily access cash at any time.

Table 6: Number of Functional ATM Terminals of other Banks Accessible by Users of E-Banking at Ecobank in Benue State.

\begin{tabular}{|l|l|l|}
\hline Number of ATM Terminals & Frequency & Percentage \\
\hline $1-4$ & 201 & 53.20 \\
\hline $5-9$ & 95 & 25.10 \\
\hline 10 and above & 82 & 21.70 \\
\hline Total & $\mathbf{3 7 8}$ & $\mathbf{1 0 0 . 0 0}$ \\
\hline
\end{tabular}

Source: Field Survey, 2014.

Table 6 shows the number of functional ATM terminals of other banks accessible to users of E-banking at Ecobank. It shows that $53.2 \%$ of Users of E-banking at Ecobank Nigeria in Benue State have access to 1-4 ATM terminals of other banks in addition to the Ecobank ATMs; while 25.1\% of Users have access to 5-9 ATM terminals in addition to Ecobank ATMs and 21.7\% have access to 10 and above ATMs of other banks in addition to Ecobank's ATMs. This suggests that accessibility to cash withdrawal channels via the ATM is sufficient to meet their daily cash withdrawal needs to the limit allowed on ATM.

Table 7: Average Uptime (in \%) of Ecobank ATM and Mobile Money in Benue State.

\begin{tabular}{|l|l|l|}
\hline & Frequency & Percentage \\
\hline Average Uptime (\%) & & \\
\hline $90-95$ & 71 & 18.80 \\
\hline $96-98$ & 175 & 46.30 \\
\hline $99-100$ & 132 & 34.90 \\
\hline Total & $\mathbf{3 7 8}$ & $\mathbf{1 0 0 . 0 0}$ \\
\hline
\end{tabular}

Source: Field Survey, 2014

Table 7 was used to assess the average uptime of Ecobank ATMs and Mobile Money in the state. The table shows that $18.8 \%$ of Users of E-banking at Ecobank Nigeria, have indicated there is an average uptime of $90-95 \%$ for both ATM and Ecobank Mobile Money; and 46.3\% of Users indicated that there is an average uptime of 96-98\% for use and 34.9\% of Users reported that there is $99-100 \%$ average uptime for ATM and Ecobank Mobile Money at Ecobank Nigeria in Benue State.Juxta posing these responses with the standard of the Service Level Agreement (SLA) of Ecobank which stipulates 95\% average uptime of ATMs and Mobile Money as the minimum acceptable average uptime for all E-channels; it can be said that, E-banking platforms at Ecobank are readily available and functional for users to perform transactions. In assessing the efficiency of E-banking at Ecobank Nigeria in Benue State, tables 8 and 9 were presented on both users and non-users E-banking services.

Table 8: Reasons for using ATM and Mobile Money at Ecobank Nigeria in Benue State by Users of Ebanking

\begin{tabular}{|l|l|l|}
\hline Reasons & Frequency & Percentage \\
\hline Convenience \& Time Saving & 282 & 74.60 \\
\hline Reduced Cost of Transportation & 96 & 25.40 \\
\hline Total & 378 & 100 \\
\hline
\end{tabular}

Source: Field Survey, 2014.

Table8 reveals the major reasons why customers of Ecobank Nigeria in Benue State prefer the usage of E-banking to Hall banking, which includes convenience and time saving and reduced cost of transportation. 
Majority of the Users (that is, $74.60 \%$ ) have indicated convenience and time saving as the core reason for using Ebanking while $25 \%$ gave credence for the reduction in transportation cost. This suggests that using E-banking platforms will give them relative comfort and will reduce the time that otherwise would have been spent on the queue in the banking hall. This finding corroborates the findings of Auta (2010) who found that E-banking provides transaction-related benefits like easy transfer of funds, less cost, and time savings.

Table 9: Reasons for Using Hall Banking at Ecobank Nigeria in Benue State by Non-users.

\begin{tabular}{|l|l|l|}
\hline Reasons & Frequency & Percentage \\
\hline Cash Withdrawal limit & 225 & 46.58 \\
\hline Fear of Fraudsters & 156 & 32.30 \\
\hline Network problem & 102 & 21.12 \\
\hline Total & $483^{*}$ & 100.00 \\
\hline
\end{tabular}

Source: Field Survey,2014.

*Respondents were allowed to give more than one challenge

Table 9 shows that 225 customers representing $46.58 \%$ of Non-users have indicated the cash withdrawal limit as a reason for using banking hall services instead of electronic channels; while 156 customers representing $32.30 \%$ of the Non-users advanced fear of fraudsters as a reason for preferring banking hall services to E-banking and lastly, 102 customers representing $21.12 \%$ of the Non-users indicated network problem as reason for using banking hall services instead of electronic channels.

The table shows three major reasons why customers at Ecobank Nigeria in Benue State prefer hall banking to Ebanking. The major reason advanced by Non-users is the cash withdrawal limit that is imposed on the usage of Ebanking at Ecobank Nigeria. This may be because of the maximum daily limit of $\$ 150,000$ withdrawal from the ATM for customers ofEcobank, and the maximum of $\$ 1,000,000$ transfer via Ecobank Mobile Money daily. Some of these customers (Non-users) are involved in cash based business transactions above thresholds of Ecobank Nigeria daily cash withdrawal and transfer limits.

At this point, it becomes pertinent to assess the efficiency of these platforms in terms of time spent, cost involved, the volume of cash withdrawal and cash deposit and issuance of a bank draft.

Figure 1: Time Spent on Queue For Users of ATM and Banking Hall at Ecobank Nigeria.

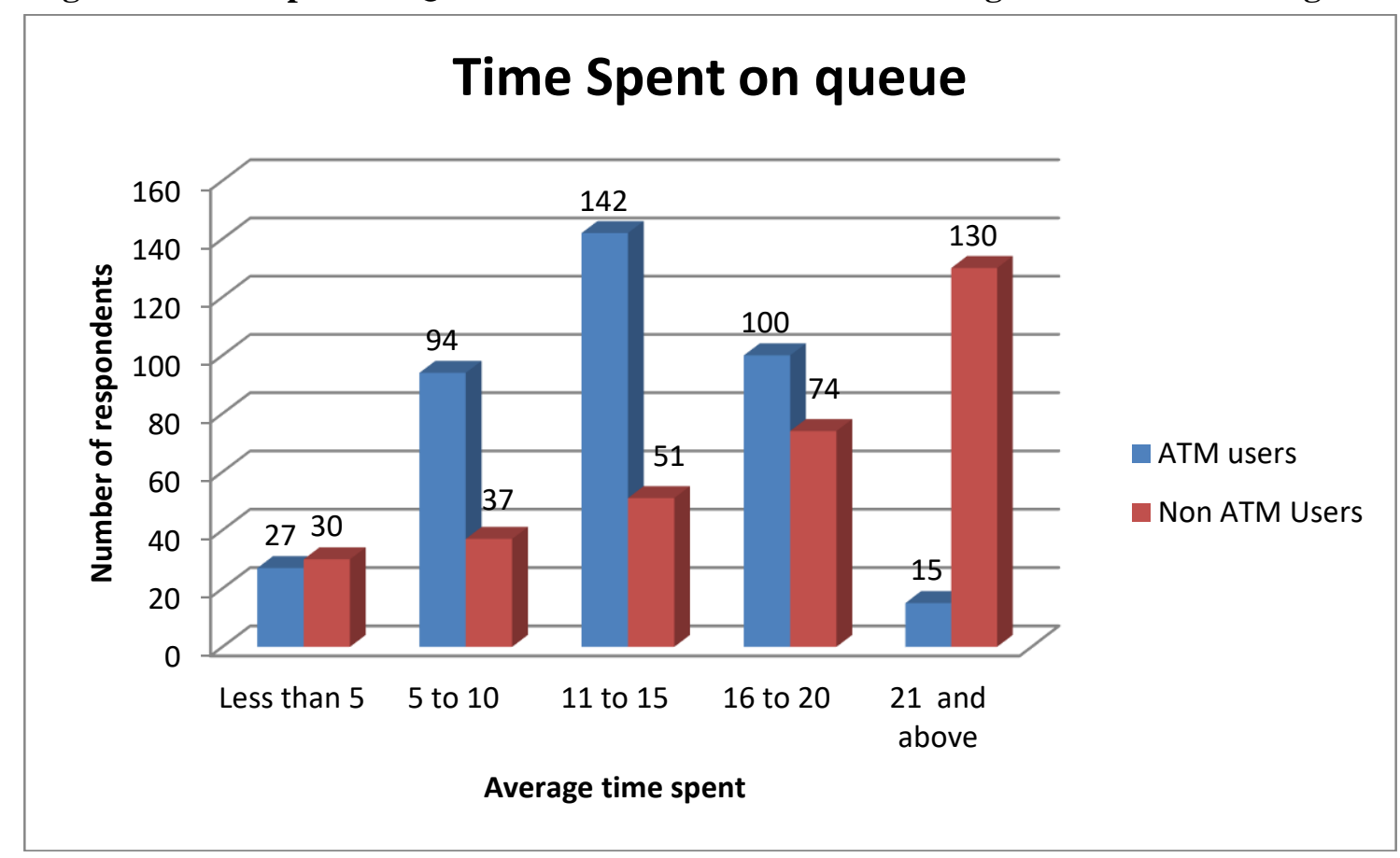

From the figure, it can be seen that the longest time spent on the queue by Users of ATM is between 11 to 15 minutes while the longest time spent on the queue by Non-users is 21 minutes and above. This shows that using ATM saves time than non-users of ATM spent in the banking hall. 
Furthermore, effectiveness was assessed in terms of transportation cost and the cost incurred in using a particular Ecobank platform. The responses of Users and Non-users are presented in Table 10.

Table 10: Transportation cost incurred by Users and Non-users in accessing the platforms.

\begin{tabular}{|l|l|l|l|l|}
\hline Cost (N) & Users & Non-users \\
\hline & Frequency & Percentage & Frequency & Percentage \\
\hline Less than 100 & 176 & 46.60 & 78 & 24.20 \\
\hline $100-200$ & 131 & 34.70 & 106 & 32.90 \\
\hline 201 and above & 71 & 18.80 & 138 & 42.90 \\
\hline Total & 378 & 100.00 & 322 & 100.00 \\
\hline
\end{tabular}

Source: Field Survey, 2014.

It is assumed in this work that an average cost of intra-transport in Benue State is \$50; however, it cost more in relation to distance. From Table 10, 176 customers representing 46.60\% of Users of E-banking facilities have indicated that they spend less than $\$ 100$ to access ATM terminals; while 78 customers representing $24.20 \%$ of Non-users indicated that they spend less than $\$ 100$ to access a bank branch. Also, the table shows that 131 customers representing $34.70 \%$ of the Users of E-banking indicated that they spend between $\$ 100$ to $\$ 200$ on transportation to access ATM terminals; while 106 customers representing $32.90 \%$ of the Non-users have indicated that they spend between $\$ 100$ to $\$ 200$ to access an Ecobank branch. Furthermore, the table reveals that 71 customers representing $18.80 \%$ of the Users of E-banking (ATM) said that they spend 201 and above on transportation to access ATM terminals; while 138 customers representing $42.90 \%$ of the Non-users of E-banking indicated that they spend $\$ 201$ and above to access an Ecobank branch. The table reveals that majority (that is $46.6 \%$ ) of the users of E-banking indicated that they spend less than $\$ 100$ for transportation to access ATM terminals. This suggests that ATMs are easily accessible relative to the bank branches; this is further supported by a higher percentage of Non-users (i.e 32.9\%) for an amount ranging $\$ 100-\$ 200$, and $42.9 \%$ for $\$ 201$ and above who have indicated that they spend higher amounts for transport in accessing the banking halls for banking services. Table 11 solicits information on the cost for using any of the platforms such as ATM and Banking hall services.

Table 11: Responses on whether or not it Cost for Using the Platforms (E-banking and Banking Hall) by Users and Non-users.

\begin{tabular}{|l|l|l|l|l|}
\hline Responses & Users & Non-users \\
\hline & Frequency & Percentage & Frequency & Percentage \\
\hline It cost & 0 & 0 & 322 & 100.00 \\
\hline It does not cost & 378 & 100.00 & 0 & 0 \\
\hline Total & 378 & 100.00 & 322 & 100.00 \\
\hline
\end{tabular}

Source: Field Survey, 2014.

Table 11 shows 322 customers representing 100\% of Non-users revealed that it cost them using the banking hall for financial transactions while 378 customers representing $100 \%$ of the Users of E-banking facility (ATM) have indicated that it does not cost them for using the ATM. Thus, the users and Non-users were further asked to indicate cost they incur in using the banking hall services for their banking transactions. The table shows that 70 customers representing $21.70 \%$ of the Non-users of ATM spend between $\$ 100$ and $\$ 251$ above for using the banking hall for financial transactions; while 378 customers representing 100\% of the Users (Mobile Money) have indicated that it cost less than $\$ 100$ for using E-banking facility (Eco Mobile Money) for fund transfers.

Table 12: Cost incurred by Non-users in Using Banking Hall Services and Users of Ecobank Mobile Money for cash withdrawals and transfers

\begin{tabular}{|l|l|l|l|l|}
\hline & Non-users & \multicolumn{2}{l|}{ Users (Mobile Money) } \\
\hline Amount(N) & Frequency & Percentage & Frequency & Percentage \\
\hline Less than 100 & 70 & 21.70 & 378 & 100 \\
\hline $100-250$ & 185 & 57.50 & 0 & 0 \\
\hline 251 and above & 67 & 20.80 & 0 & 0 \\
\hline Total & $\mathbf{3 2 2}$ & $\mathbf{1 0 0 . 0 0}$ & $\mathbf{3 7 8}$ & $\mathbf{1 0 0 . 0 0}$ \\
\hline
\end{tabular}

Source: Field Survey, 2014. 
The implication is that Users of EcoMobile Money where these charges are minimal (less than $\$ 100$ ) stand the benefit of saving the cost incurred by the Non-users. Also, it shows that all the users of Ecobank Mobile Money incur cost less than $\$ 100$ for all transactions on the platform relative to high cost ( 100 to $\$ 250$ and above) associated with the banking hall services. Table 13 shows the cash withdrawal limit by both users and non-users of E-banking at Ecobank.

Table 13:Daily Cash withdrawal limit for both Users and Non-users of E-banking atEcobank Nigeria in Benue State

\begin{tabular}{|l|l|l|l|}
\hline & Cash Limit (\$) & Frequency & Percentage \\
\hline Users & 150,000 & 378 & 100 \\
\hline Non-users & $3,000,000$ & 322 & 100 \\
\hline
\end{tabular}

Source: Field Survey, 2014.

The table reveals that 378 customers representing $100 \%$ of the Users of E-banking (ATM) indicated that they can withdraw a maximum of $\$ 150,000$ daily; while 322 customers representing $100 \%$ of the Non-users have indicated that they could withdraw a maximum of $\$ 3,000,000$ daily via the banking hall. The table shows that the daily cash withdrawal limit for Users of ATM is $\$ 150,000$; while that of Non-users is $\$ 3,000,000$ in the banking hall. This implies that it will take Users of ATM 20days to withdraw $\$ 3,000,000$.This suggests that the Non-users have more access to physical cash to transact businesses in a day than the users of ATM. Table 14 provides information on cash deposits and assessing bank draft using any platform by both Users and Non-users. The table also shows that 378 customers representing 100\% of the Users of E-banking indicated that they cannot deposit cash and raise bank draft while 322 customers representing $100 \%$ of Non-users have indicated that they can deposit cash and raise bank draft via the banking hall.

Table 14: Cash deposits and Bank draft by users and Non-users of E-banking Platform

\begin{tabular}{|l|l|l|l|l|}
\hline Responses & Users & Non-users \\
\hline & Frequency & Percentage & Frequency & Percentage \\
\hline Can deposit and raise draft & 0 & 0 & 322 & 100.00 \\
\hline Cannot deposit and raise draft & 378 & 100.00 & 0 & 0 \\
\hline Total & 378 & 100.00 & 322 & 100.00 \\
\hline
\end{tabular}

Source: Field Survey, 2014.

This suggests that the Users of E-banking platforms cannot perform certain bank transactions such as cash deposit, issuance of bank draft and some inquiries that demand the physical attention of bank staff through the ATM and mobile phone. However, the Users of E-banking who have the liberty to use both media (E-banking facilities and Banking hall) can use the banking hall to carry out these transactions. Kolmogorov-Smirnov, Shapiro-Wilk, and Satterthwaite-Welch t-test were used to ascertain the difference on the basis of time spent on queues and financial cost by users of E-banking and non-users. Table 15 shows the Kolmogorov-Smirnov and Shapiro-Wilk tests for the time spent on the queue for ATM and Banking hall services.

Table 15: Kolmogorov-Smirnov and Shapiro-Wilk Tests for Time Spent on Queue.

\begin{tabular}{|l|l|l|l|l|l|l|l|l|}
\hline & \multicolumn{4}{|l|}{ Kolmogorov-Smirnov } & \multicolumn{2}{l|}{ Shapiro-Wilk } \\
\hline Platforms & Mean & Statistic & Df & Sig & Mean & Statistic & Df & Sig. \\
\hline E-banking & 3.24 & & 321 & 0.00 & 3.24 & & 321 & 0.00 \\
\hline & & 3.287 & & & & 3.862 & & \\
\hline Banking Hall & 36.31 & & 377 & 0.00 & 36.31 & & 377 & 0.00 \\
\hline
\end{tabular}

Source: Extract from SPSS output.

The table shows the mean time of 3.24 minutes for Users of E-banking at Ecobank Nigeria in Benue State and 36.31 minutes for banking hall services. The calculated Kolmogorov-Smirnov test value of 3.287 is greater than the table value of +1.832 . This implies that there is a significant difference between the time spent on the queue in the banking hall and on the queue in the use of E-banking at Ecobank Nigeria in Benue State. The difference in the time spent on the queue in the banking hall and on the queue in the ATM is 33.07 minutes. The ShapiroWilktest was also used to confirm the results of the Kolmogorov-Smirnov test. 
The Shapiro-Wilk test reveals a value of 3.862 which is also statistically significant at $1 \%$ level since the probability value of $(0.00)$ is less than the cut off probability value of $\mathrm{P}=0.01$; therefore, confirming the Kolmogorov-Smirnov test that there is significant difference between time spent on queue using the banking hall services and the E-banking. In order to check the correctness of the tests, we further use the Satterthwaite-Welch t-test. The result is shown in table 16.

Table 16: The SatterThwaite-Welch t-test for Equality of Means between Series

\begin{tabular}{|l|l|l|l|}
\hline Platforms & Means & t-test & Df \\
\hline E-banking & 3.24 & & \\
\hline & & -41.95 & 698 \\
\hline Banking Hall & 36.31 & & \\
\hline
\end{tabular}

Source: Extract from SPSS.

The Satterthwaite-Welch t-test for equality of means between series shows a value of -41.95 which is greater than the table value of \pm 2.281 . This implies that there is a significant difference in the time spent on the queue in using E-banking and in banking hall services. This further confirms the Kolmogorov-Smirnov test. Table 17 was used to assess the financial cost for using E-banking and the banking hall. To achieve this, the KolmogorovSmirnov and Shapiro-Wilk test was used. The table shows the Mean Financial Cost for Users of E-banking as $\$ 80.51$ and $\$ 274.81$ for users of Banking Hall services at Ecobank Nigeria, Benue State. The KolmogorovSmirnov calculated value of 4.488 is greater than the table value of +1.832 . This implies that there is a significant difference in the cost incurred by Users of E-banking and that of users of Banking Hall Services. That is the financial cost difference of N194.30.

Table 17: Kolmogorov-Smirnov and Shapiro-Wilk Tests for Financial Cost.

\begin{tabular}{|l|l|l|l|l|l|l|l|l|}
\hline & \multicolumn{4}{|l|}{ Kolmogorov-Smirnov } & \multicolumn{4}{l|}{ Shapiro-Wilk } \\
\hline Platform & Mean & Statistic & DF & Sig. & Mean & Statistic & DF & Sig \\
\hline E-banking & 80.51 & & 377 & 0.00 & 80.51 & & 377 & 0.00 \\
\hline & & 4.488 & & & & 5.516 & & \\
\hline Banking Hall & 274.81 & & 321 & 0.00 & 274.81 & & 321 & 0.00 \\
\hline
\end{tabular}

Source: Extract from SPSS

Furthermore, the Shapiro-Wilk test was also used to confirm the results of the Kolmogorov-Smirnov test. The Shapiro-Wilk test reveals a value of 4.488 which is statistically significant at $1 \%$ level since the probability value of $(\mathrm{P}=0.00)$ is less than the cut off probability value of $(\mathrm{P}=0.01)$, therefore, confirming the Kolmogorov-Smirnov test that there is a difference between the costs incurred by Users of E-banking and users of banking Hall at Ecobank Nigeria in Benue State. Table 18.presents the Satterthwaite-Welch t-test used to check the correctness of the two tests.

Table 18: The Satterthwaite-Welch t-test for Equality of Means between Series

\begin{tabular}{|l|l|l|l|l|}
\hline Platforms & Means & t-test & Df & Probability \\
\hline E-banking & 80.51 & & & \\
\hline & & -14.70 & 698 & 0.00 \\
\hline Banking Hall & 274.81 & & & \\
\hline
\end{tabular}

Source: Extract from SPSS

The test shows a value of -14.70 which is greater than the table value of +2.281 . This implies that there is a significant difference in the cost incurred in using E-banking and Banking hall services at Ecobank Nigeria in Benue State. This further confirms the Kolmogorov-Smirnov test given that the results in Tables 15, 16, 17, and 18 respectively have indicated that there is a significant difference in the Time Spent and the financial cost between the Users and Non-users of E-banking at Ecobank in Benue State. We, therefore, say that Non-users of E-banking spend a considerable higher amount of Time (33.07 minutes) and Money (N194.3) in accessing services in Ecobank in Benue State. 
Table 19: Challenges of E-banking on Service Delivery at Ecobank

\begin{tabular}{|l|l|l|}
\hline Nature of the Problem & Frequency & Percentage \\
\hline Network Failure & 378 & 49.15 \\
\hline Cash Retract Problem & 211 & 27.44 \\
\hline Unapplied Funds & 128 & 16.64 \\
\hline Others & 52 & 6.76 \\
\hline Total & $\mathbf{7 6 9} *$ & $\mathbf{1 0 0 . 0 0}$ \\
\hline
\end{tabular}

Source: Field Survey, 2014.

*Respondents were allowed to give more than one challenge.

Table 19 was used to show the problems faced in the use of E-banking at Ecobank Nigeria in Benue State. The table indicates that $49.15 \%$ of users of E-banking have indicated network failure challenge and $27.44 \%$ indicates cash retract problems while about $17 \%$ represents the problem of unapplied funds. This result shows that the essence of 24hours access to cash via E-channels may be defeated as a result of internet network failure. Analogous to table 19 is the response in table 20 which shows the response between users and non-user as par network challenges. The table shows that all the 378 Users of E-banking sampled in this study reported network problem as the major challenge; while 286 of Non-users representing $88.82 \%$ indicated that network problem is a challenge in the use of banking hall services.

Table 20: The Responses of Users and Non-users to Network Challenge

\begin{tabular}{|l|l|l|}
\hline Groups & $\begin{array}{l}\text { Responses on Network } \\
\text { Challenge }\end{array}$ & Percentage \\
\hline Users & 378 & 100.00 \\
\hline Non-users & 286 & 88.82 \\
\hline
\end{tabular}

Source: Field Survey, 2014.

This implies that network problem is not peculiar to the use of E-banking but also to banking hall services. The reason why there are fewer responses by Non-users as regards network challenge is that in the incidence of network failure in the banking hall, the bank in some cases uses backend ledger to attend cash withdrawal request of customers withdrawing below $\$ 20,000$. This is not applicable to Users of E-banking.

\section{Conclusion}

Based on the findings of this study, it was concluded that E-banking has enhanced efficiency in service delivery at Ecobank Nigeria in Benue State as regards to time-saving, and cost-effectiveness in relation to the use of banking hall. However, E-banking has not attained its expected level of efficiency as a result of certain challenges accompanied in the use of this platform such as Network failure; Cash retracts issue, internet fraud and unapplied funds for transfers via Mobile Money and ATM.

\section{Recommendations}

Based on these findings, the following recommendations are made. Banks should invest more on Information and Communication Technology (ICT) ona higher version of radio wave like fiber and subscribe to Internet Service Provider (ISP) with higher bandwidth to enable them to render the expected service to the end-users. Banks should decentralize the resolution of cash retract and unapplied funds to allow customers to have quicker access to their unapplied funds. Banks should also invest heavily in Research and Development ( R \& $D$ ) to provide innovations on how to secure customers' transactions on the internet from fraudsters as this would boost more confidence in the usage of E-banking products by customers. As a regulatory body, the Central Bank of Nigeria $(\mathrm{CBN})$ should fully implement its cashless policy so as to encourage the use of E-banking in the country. This is because the cashless policy that limits the usage of cash for business transactions, the Users of E-banking who have the liberty to use both media (Banking Hall and E-banking facilities) for cash withdrawal will upon full implementation of the cashless policy have more access to cash than their Non-users counterpart. The implication then is that the usage of ATM and Mobile Money banking would be more beneficial in terms of volume of cash available to the users of these platforms. 


\section{References}

Abaenewe, Z. C., Ogbulu, O. M., and Ndugbu, M. O. (2013).Electronic banking and bank performance in Nigeria.West African Journal of Industrial \& Academic Research,6(1), 75-124.

AlAbdullah, F.S.,Alshammari,F.H.,Alnaqeib, R.,Jalab,H. A.,Zaidan, A.A., and Zaidan, B.B.(2010). Analytical study on internet banking system. Journal of Computing,2(6), 140-146.

Antony, J. (2011). E - banking as a tool for enhancing customers' satisfaction in the banking sector. A Study of First Bank Plc. Published thesis to the department of business administration, faculty of administration, Ahmadu Bello University.

Arnaboldi, F.,andClaeys, P. (2008). Internet banking in Europe: A comparative analysis. Research Institute of Applied Economics, Working Papers.

Auta, E.M. (2010) E-banking in developing economy: Empirical evidence from Nigeria. Journal of Applied Quantitative Methods, 5(2), 65-135.

Baraghani,S.N. (2008).Factors influencing the adoption of internet banking. Division of industrial marketing and e-commerce.Lulea University of Technology.

Bello, D. A.(2005).The impact of E-banking on customer satisfaction in Nigeria. Munich Personal RePEc Archive (MPRA) Paper No. 23200.

Berger, A. N. (2003). The economic effects of technological progress: Evidence from the banking industry. Journal of Money, Credit, Banking, 35 (2),141- 176.

Durkin, M. (2004). In search of the internet-banking customer: Exploring the use of decision styles. The International Journal of Bank Marketing,22 (7), 484-503.

Hong, Y.H.,Teh,B.H.,Vinayan, G.,Soh, C.H., Khan, N., and Ong, T.S.(2013). Investigating the factors influence adoption of internet banking in Malaysia: Adopters perspective, International Journal of Business and Management; 8(19), 24-31.

Karjaluoto, H. (2002). Electronic banking in Finland consumer beliefs, attitudes, intentions and behaviors.Academic dissertation submitted to the school of business and economics of the University of Jyväskylä.

Leblanc, G. (1990). Customers' motivations: use and non-use of automated banking. International Journal of Bank Marketing, 8(4), 36-40.

Lewis, B. R. (1991)."Service quality: an international comparison of bank customers expectations and perceptions", Journal of Marketing Management, 7(1), 47-62.

Ling,G.M., Fern, Y.S., Boon, L.K., and Huat, T.S. (2006). Understanding customer satisfaction of internet banking: A case study in Malacca, Procedia Economics and Finance, 37, 80-85.

Malhotra, P., and Singh, B. (2006).The impact of internet banking on bank performance: The Indian experience. Academic Journal Article from South Asian Journal of Management, 13(4), 154-162.

Marshall, J.,andHeslop, L. (1988). Technology acceptance in Canadian retail banking. International Journal of Bank Marketing, 6(4), 31-41.

Mohammed, S.,Aminul H. R., andLakkhan C. R. (2015).Analysis of factors affecting the customer's satisfaction with reference to ATM Services in Dhaka City.IOSR Journal of Business and Management,17(1), 68-75.

Muzividzi, D.K .,Mbizi,R., andMukwazhe, T.(2013).An analysis of factors that influence internet banking adoption among intellectuals: Case of Chinhoyi University of Technology.Interdisciplinary Journal of Contemporary Research in Business Institute of Interdisciplinary Business Research, 4 (11).

Ogunlowore, A. J., and Oladele, R. (2014). Analysis of electronic banking and customer satisfaction in Nigeria. European Journal of Business and Social Sciences, 3(3), 14-27.

Olanipekun, W.,Brimai, A.,andAjagbe, S. (2013). The role of electronic banking in enhancing human resource performance and customer satisfaction: Evidence from Guaranty Trust Bank PLC, Nigeria.International Journal of Business and Behavioural Sciences,3(4), 156-168.

Okiro, K., and Ndungu, J. (2013).The impact of mobile and internet banking on performance of financial institutions in Kenya.European Scientific Journal, 9(13), 1857 - 7881.

Osabuohien, E.S.C. (2008).ICT and Nigerian banks reforms: Analysis of anticipated impacts in selected banks.Global.Journal of Business Research, 2(3), 175-201.

Owusu-Afriyie, M. (2012).Assessment of knowledge and utilization of E-banking facilities in Ghana commercial bank limited in the YiloKrobo and the Asuogyaman District Assemblies. An Unpublished Thesis submitted to the Institute of Distance Learning, Kwame Nkrumah university of science and technology 
in partial fulfillment of therequirements for the degree of Commonwealth Executive Masters in BusinessAdministration,September.

Polatoglu, V.N., andEkin, S. (2001).An empirical investigation of the Turkish consumers' acceptance of internet banking services.International Journal of Bank Marketing 19940 156-165.

Ranee, J. (2008).Impact of ICT in the banking sector. A Paper presented at the Trans Asia, Colombo,22 January. Rogers, E.M. (2003)Diffusion of innovations, 5th ed.New York: Free Press.

Rugimbana, R.O., andIversen.P. (1994).Perceived attributes of ATMs and their marketing implications. The International Journal of Bank Marketing, 12(2), 30-35.

Sailaja, P., andThamodaran, V.(2016). Customer perception on security systems in E-Banking services with special references to ATM. Imperial Journal of Interdisciplinary Research, 2(6), 426-432.

Sathye, M. (1999), Internet banking in Australia.Journal of Internet Banking and Commerce, 2(4).

Yamane, T. (1967). Statistics: An introductory analysis, 2nd Ed., New York: Harper and Row.

Zeithaml, V.,andGilly, M.C. (1987). Characteristics affecting the acceptance of retailing technologies: A comparison of elderly and non-elderly consumers. Journal of Retailing 63(1), 49-68. 